\author{
Marek Nowacki \\ https://orcid.org/0000-0002-6981-7698 \\ WSB University in Poznan \\ Faculty of Finance and Banking \\ Department of Socio-Economics \\ marek.nowacki@wsb.poznan.pl
}

\title{
UNIQUE ELEMENTS OF POLISH CITY BRANDS IN ONLINE REVIEWS
}

\begin{abstract}
The aim of the paper is to identify unique elements of the brands of Polish cities and to identify similarities and differences between them. The work attempts to answer the following research questions: Which elements significantly differentiate the brands of studied cities in online reviews? and Which of the studied cities are the most similar in terms of brand elements and which differ in this regard. The data for analysis was obtained from TripAdvisor. Reviews about areas of tourist concentration - old markets or old towns - from five Polish cities: Poznań, Wrocław, Kraków, Gdańsk and Warsaw were analysed $(\mathrm{N}=5125)$. The research shows that Gdańsk and Warsaw as well as Poznań and Wrocław have the most similar brand elements. The Kraków brand is the more unique in relation to other cities.
\end{abstract}

Keywords: brand equity, destinations, cities, TripAdvisor, Text Mining.

\section{INTRODUCTION}

Brand according to Kotler, Bowen, Makens \& Baloglu (2017) is a name, sign, symbol, design, or a combination of these elements that is intended to identify goods or services and differentiate them from competitors. The possibilities of using the brand concept in relation to tourist destinations have been confirmed by many authors (Buhalis, 2000; Konecnik, Gartner, 2007; Woodside, Cruickshank, Dehuang, 2007). Branding is a process of endowing products and services with the power of the brand and its main purpose is to create differences between products (Kotler et al., 2017). Branding is currently considered an extremely important aspect of the destination management practice, as the growing opportunities for tourist trips and the number of available destinations result in increased substitution and lack of differentiation between destinations (Pike, 2005). According to Aaker (2009), brand equity is a set of assets and liabilities to a brand, its name and symbol, that add to or subtract from the value provided by a product or service to a firm and/or to that firm's customers. Hence, in the context of destination management, an important research task is to study the perception of brands, their equity and impact on consumer behavior in tourism.
Brand equity can be identified in two ways. First, as an indicator of the financial result that the organization owes to the brand, and secondly, brand equity can be assessed from the consumers' perspective (Boo, Busser, Baloglu, 2009). This is the so-called customer-based brand equity (CBBE). Keller (1993, p. 8) defines it as "the differential effect of brand knowledge on consumer response to the marketing of the brand". This means that it is based on the associations and attitudes of the brand users. Aaker (2009, pp. 15-16) lists the following dimensions of brand equity: brand loyalty, brand awareness, perceived quality, brand associations and other assets such as patents, trademarks, channel relationships, etc. The first four of these dimensions are related to customer-based brand equity. Florek (2014) lists two dimensions of brand equity sources: perceived (measured by brand awareness, associations, image, perceived quality) and behavioural (measured by brand loyalty, willingness to pay or recommendation).

The concept of brand equity in reference to place was first formulated by Papadopoulos (2004, p. 43): these are "the real and/or perceived assets and liabilities that are associated with a place (country) and distinguish it from others". 
Konecnik \& Gartner (2007), in one of the first empirical works about destination brand equity, proposed a customer-based brand equity model using the perception of tourists. As a result of surveys conducted among Croatian and German tourists, they found the existence of four dimensions to Slovenia's brand equity: awareness, image, quality and loyalty. They identified a number of relationships between these dimensions and stated that the image is a central concept in destination branding. It turned out, however, that when the destination brand becomes known to consumers, the image is transferred to the other dimensions of the brand and is obscured by it. Konecnik \& Gartner (2007) noticed also that the other dimensions of brand equity affect the dimensions of the image (Fig. 1). For example, brand awareness has an impact on the cognitive dimension of the image, without which there is no brand equity. The dimensions of the image and quality of the brand have the strongest impact on the affective dimension of the image. In turn, loyalty to the brand influences the conative dimension of the image. Thus, both the interrelationships between the dimensions of the image, and the cumulative equity of the brand components, create the brand equity of the destination, in total.

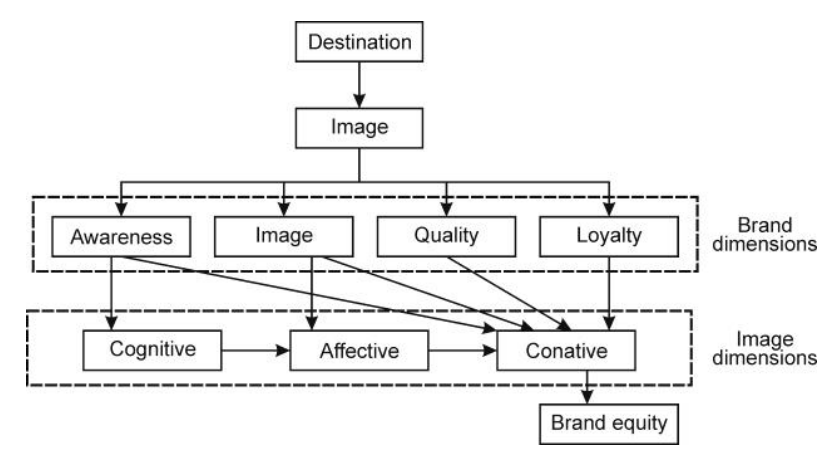

Fig. 1. Destinationbrand equity development Source: Konecnik \& Gartner (2007, p. 403); author's elaboration

Another very interesting study was conducted by Boo et al. (2009) among American tourists. They have done online research among Las Vegas and Atlantic City guests. Researchers constructed and tested specific scales to measure four dimensions of the gambling destination brand. They stated that it is possible to study the destination brand equity using the CBBE model, but these brands should be evaluated by comparison with other competing destinations in the same category. Brands tested in this way should be popular and well known to the participants. Researchers found that when a destination brand is researched, a specific scale has to be constructed that takes into account the nature of the areas being compared.

In another article, Lucarelli (2012) reviewed 217 English-language articles published between 1990 and 2009. He proposed a three-dimensional, interdiscipli- nary model of analysis and assessment of a city's brand equity including elements of the city brand, measurement of the impact of city brands and the impact of branding on cities.

Interesting research on consumer-based city brand equity was made by Florek (2014). As a result of surveys conducted among the residents of Poznan and Wrocław, the author has distinguished four dimensions of city brand equity: attachment, perception, recommendation and satisfaction.

Based on a literature review, Leicht (2016) formulated criteria to select areas for brand comparison to guarantee external validity. These are:

- comparable area, e.g. city vs city, region vs region,

- spatial and cultural context that offers at least certain degree of differentiation, e.g. location in different places and/ or cultural spheres,

- comparable types of place, product or service offered.

\section{REVIEWS AVAILABLE ONLINE, BIG DATA AND TEXT MINING}

The information passed from 'mouth to mouth' (word of mouth - WOM) is an important factor in the process of shaping a destination image (Brown, Getz, 2005; Jalilvand, Shekarchizadeh, Samiei, 2011). However, with the emergence of social media, Internet $2.0^{1}$ and user generated content (UGC), this phenomenon began to take on a whole new character. Numerous online travel forums and opinion aggregators, such as TripAdvisor, Lonely Planet or Ciao, provide countless pieces of information that significantly affect the consumer decisions of their users. This form of information transfer is referred as electronic word of mouth (eWOM) and is considered to be the most influential source of information nowadays (Jalilvand, 2016).

Cantallops \& Salvi (2014) as well as Casalo, Flavian, Guinaliu \& Ekinci (2015) stated that eWOM has the greatest impact among all sources of information on consumers of tourist services and this is mainly due to their intangible nature. Millions of reviews available online $^{2}$ consistently create a huge and diverse set of data known as Big Data, whose processing, using computer algorithms (Data Mining and Text Mining), enables new, previously unavailable knowledge to be found (Kuhzady, Ghasemi, 2019; Liu, Huangb, Bao, Chenc, 2019; Nowacki, 2019).

Text Mining refers to the process of acquiring highquality information from text data and covers a wide range of topics and algorithms for text analysis, covering various communities and including information retrieval, natural language processing, data mining and machine learning (Allahyari et al., 2017). With the 
advent of e-commerce and online shopping, a huge number of product reviews and user reviews have been emerging, and are still growing. By analysing such data, one can get important information and opinions on topics that are essential in online advertising and marketing (Allahyari et al., 2017).

\section{AIM OF THE WORK AND RESEARCH QUESTIONS}

Searching for characteristic elements of destination brands can be carried out by analysing online reviews in two ways: qualitatively and quantitatively. Qualitative research has been conducted, among others by Niezgoda (2017) and she identified three dimensions of the images of the palaces at Versailles and Caserta in the reviews available on TripAdvisor. The Greek researchers Kladou \& Mavragani (2015) identified the dimensions of Istanbul's image, while Nowacki (2017) identified the features of global city images. Quantitative research was also carried out, such as the identification of cultural experiences among people visiting the cultural attractions of Naples (Simeon, Buonincontri, Cinquegrani, Martone, 2017), unique words associated with the Balkans (Smith et al. 2018) or the characteristic words of the Barcelona brand (Tamajón, Valiente, 2015). Interesting research was also performed by Nakaima, Marchiori \& Cantoni (2019) who identified tourists' experiences from visiting ten islands which were popular holiday destinations. Data analysed were opinions obtained from TripAdvisor.

In the light of the above findings, it can be concluded that there is a gap in identification of characteristic brand elements of destinations (see Lucarelli, 2012, p. 236), especially using the comparative method, Big Data, Text Mining and advanced statistical methods.

Therefore, the aim of this research is to identify the characteristic elements of Polish city brands and to indicate the similarities and differences between them. The following research questions were formulated:

$R Q$ 1: What brand elements significantly differentiate the examined cities in online reviews?

RQ 2: Which cities are the most similar to each other in terms of identified brand elements and which are different?

\section{METHOD}

Reviews available on the English-language portal TripAdvisor were used as research material (TripAdvisor, 2019). The categories of review were selected from available tourist attractions in the examined cities ("Things to do in ...'): in the centre, in the old town or old market, i.e. in the main tourist concentration zones in the city (see also Kladou, Mavragani, 2015). There are many different tourist attractions in these districts, such as churches, town halls, monuments, fountains, museums, restaurants, hotels, souvenir shops, tourist information points and more.

The five most popular tourist cities in Poland were selected for research, i.e. Poznań, Wrocław, Warsaw, Gdańsk and Kraków. For Poznań and Wrocław, reviews of the Old Market Square were analysed, while in the other cities - Old Town districts (there is no Old Town category in TripAdvisor for Poznań, and there are only 425 reviews for Wrocław in this category) [16.02.2019]. As the lowest number of reviews in the compared categories (Old Market Square / Old Town) was in Poznań (1026), to maintain proportion, exactly 1025 reviews were collected for each city (Table 1). The reviews were downloaded on $15^{\text {th }}$ February 2019 using the Web Scraper application (Web Scraper, 2019) and 5125 reviews for all cities were obtained in total (Table 1).

Table 1. Collected data according to city and category of tourist concentration site $(\mathrm{N}=5125)$

\begin{tabular}{|l|c|c|c|}
\hline \multicolumn{1}{|c|}{ City } & Category & $\mathrm{N}$ & $\%$ \\
\hline Poznań & Old Market Square & 1025 & 20 \\
\hline Wrocław & Old Market Square & 1025 & 20 \\
\hline Warsaw & Old Town & 1025 & 20 \\
\hline Gdańsk & Old Town & 1025 & 20 \\
\hline Kraków & Old Town & 1025 & 20 \\
\hline Total & $\mathrm{x}$ & 5125 & 100 \\
\hline
\end{tabular}

Source: author.

The data obtained were analysed using the Text Mining procedure available in the statistical package Statistica 11.0. As a first step, the frequency of words in all reviews were counted and next, the one-way analysis of variance ANOVA was carried out. As result the list of words which substantially differentiate the examined cities was found. In the last step a correspondence analysis was carried out by means of which the relationships between variables (cities) and cases (words) were examined. This allowed to illustrate obtained dependencies on a two-dimensional graph of 'city-words'.

\section{RESULTS}

At the beginning, the most common words in all reviews were counted. The set of words contained in the EnglishStopList.txt file in the package Statistica, i.e. words such as ' $a$ ', 'the', etc., were excluded from counting. Next, the lemmatization procedure (the stemming) was carried out, to reduce inflections to the dictionary 
form. Thus, the different grammatical forms of the same words were combined into one category, e.g. 'traveling', 'traveled', 'travel' etc. As a result of this procedure, a list of 105 unique words was obtained (Table 2). Next, an analysis of variance ANOVA was carried out whose aim was to find differences between the average numbers of occurrences of a given word in the reviews concerning individual cities. It turned out that 74 out of 105 words differentiate between the surveyed reviews in a significant way (Table 2).

The $\mathrm{F}$ test carried out in ANOVA indicates the significance of differences between any of the five sets of reviews for each city. To determine whether two sets of reviews for two specific cities are significantly dif- ferent from each other, for each case (word) selected in the ANOVA analysis, an additional post hoc Scheffe test was carried out (Kenneth, Bordens, Abbott, 2008, p. 432). This analysis yielded 75 unique words for the studied cities (Table 3): the most for Kraków (35), following Poznań (25), Wrocław and Warsaw (14 each) and Gdańsk (8). ${ }^{3}$ As a result of analysis, only those words were selected which significantly distinguished one or two cities (this was done in just a few cases, e.g. the figures for 'restaur' for Poznań and Wrocław were 486 and 433 respectively, and these were significantly larger than for Warsaw (273), Gdańsk (352) and Kraków (348).

As can be seen in Table 3, many of the identified words were not very characteristic and did not say

Table 2. Analysis of variance (ANOVA) of the occurrence of words in the sets of reviews concerning individual cities $(\mathrm{N}=105)$

\begin{tabular}{|c|c|c|c|c|c|c|c|c|}
\hline Word & $F$ & $p$ & Słowo & $F$ & $p$ & Word & $F$ & $p$ \\
\hline Also & 7.088 & 0.000 & Full & 5.126 & 0.000 & Pretty & 2.480 & 0.042 \\
\hline Amaze & 4.485 & 0.001 & Get & 6.770 & 0.000 & Price & 0.275 & 0.894 \\
\hline Architecture & 11.286 & 0.000 & Go & 1.342 & 0.252 & Pub & 16.524 & 0.000 \\
\hline Area & 15.086 & 0.000 & Good & 5.577 & 0.000 & Really & 2.545 & 0.038 \\
\hline Around & 3.364 & 0.009 & Great & 6.105 & 0.000 & Rebuilt & 58.471 & 0.000 \\
\hline Atmosphere & 4.610 & 0.001 & Hall & 68.695 & 0.000 & Recommend & 3.487 & 0.008 \\
\hline Aack & 3.732 & 0.005 & Historic & 22.986 & 0.000 & Restaur & 29.616 & 0.000 \\
\hline Bar & 24.999 & 0.000 & History & 31.318 & 0.000 & See & 7.343 & 0.000 \\
\hline Beauty & 6.976 & 0.000 & \begin{tabular}{|l|} 
Hour \\
\end{tabular} & 5.924 & 0.000 & Shop & 29.811 & 0.000 \\
\hline Best & 3.597 & 0.006 & Hous & 22.064 & 0.000 & Sit & 5.905 & 0.000 \\
\hline Build & 2.648 & 0.032 & \begin{tabular}{|l|} 
Interest \\
\end{tabular} & 1.431 & 0.221 & Small & 8.097 & 0.000 \\
\hline Busy & 1.127 & 0.342 & Just & 4.325 & 0.002 & Spend & 1.921 & 0.104 \\
\hline Cafe & 2.140 & 0.073 & Like & 0.931 & 0.444 & Squar & 342.014 & 0.000 \\
\hline Can & 2.058 & 0.084 & Little & 1.230 & 0.445 & Stay & 2.792 & 0.025 \\
\hline Charm & 1.961 & 0.098 & \begin{tabular}{|l|} 
Local \\
\end{tabular} & 0.876 & 0.296 & Still & 5.774 & 0.000 \\
\hline Christmas & 24.863 & 0.000 & Look & 2.438 & 0.477 & Street & 43.598 & 0.000 \\
\hline Church & 28.323 & 0.000 & \begin{tabular}{|l|} 
Lot \\
\end{tabular} & 4.847 & 0.045 & Stroll & 2.548 & 0.037 \\
\hline City & 5.533 & 0.000 & Love & 2.938 & 0.001 & Surround & 9.438 & 0.000 \\
\hline Clean & 7.796 & 0.000 & Main & 14.745 & 0.019 & Take & 6.572 & 0.000 \\
\hline Coffee & 0.441 & 0.779 & Make & 0.360 & 0.000 & Time & 1.070 & 0.370 \\
\hline Color & 18.147 & 0.000 & Many & 3.772 & 0.837 & Tour & 20.345 & 0.000 \\
\hline Colour & 21.513 & 0.000 & Market & 118.381 & 0.005 & Tourist & 0.538 & 0.708 \\
\hline Come & 3.480 & 0.008 & Much & 6.826 & 0.000 & Town & 121.924 & 0.000 \\
\hline Day & 2.794 & 0.025 & Museum & 10.610 & 0.000 & Visit & 4.310 & 0.002 \\
\hline Definite & 0.296 & 0.881 & Must & 3.959 & 0.000 & Walk & 34.767 & 0.000 \\
\hline Differ & 1.147 & 0.332 & Nice & 10.382 & 0.003 & War & 58.569 & 0.000 \\
\hline Drink & 5.785 & 0.000 & \begin{tabular}{|l|} 
Night \\
\end{tabular} & 6.928 & 0.000 & Watch & 14.786 & 0.000 \\
\hline Eat & 1.823 & 0.122 & Old & 115.270 & 0.000 & Well & 0.487 & 0.746 \\
\hline Enjoy & 2.054 & 0.084 & One & 8.581 & 0.000 & Will & 2.526 & 0.039 \\
\hline Even & 1.885 & 0.110 & Part & 15.873 & 0.000 & Wonder & 1.599 & 0.172 \\
\hline Every & 2.990 & 0.018 & People & 1.461 & 0.000 & World & 7.502 & 0.000 \\
\hline Feel & 4.145 & 0.002 & Place & 6.490 & 0.211 & Worth & 0.998 & 0.407 \\
\hline Find & 2.767 & 0.026 & Plenty & 2.365 & 0.000 & Would & 2.149 & 0.072 \\
\hline Food & 1.533 & 0.190 & Poland & 6.141 & 0.051 & & & \\
\hline Friend & 2.208 & 0.066 & Polish & 4.229 & 0.000 & & & \\
\hline
\end{tabular}

Note: words that significantly differentiate the examined cities are marked in bold.

Key: ' $F$ ' - value of the f-Fisher test, ' $p$ ' - significance of the f-Fisher test.

Source: author. 
Table 3. Unique words characteristic for each city $(\mathrm{N}=74)$

\begin{tabular}{|c|c|c|c|c|c|c|c|c|c|}
\hline \multicolumn{2}{|c|}{ Poznań } & \multicolumn{2}{|c|}{ Wrocław } & \multicolumn{2}{|c|}{ Warsaw } & \multicolumn{2}{|c|}{ Gdańsk } & \multicolumn{2}{|c|}{ Kraków } \\
\hline word & number & word & number & word & number & word & number & word & number \\
\hline Also & 99 & Atmosphere & 105 & Area & 152 & Amaze & 98 & Amaze & 90 \\
\hline Bar & 244 & Beauty & 376 & Back & 45 & Architecture & 165 & Area & 146 \\
\hline Build & 273 & Best & 59 & Feel & 53 & Build & 272 & Around & 272 \\
\hline Color & 76 & Christmas & 133 & Hour & 55 & Museum & 63 & Back & 47 \\
\hline Colour & 74 & \begin{tabular}{|l|} 
Drink \\
\end{tabular} & 98 & Nice & 231 & Small & 74 & Best & 53 \\
\hline Come & 48 & Find & 60 & Old & 597 & Stay & 52 & Church & 152 \\
\hline Day & 128 & Full & 89 & Part & 79 & Street & 257 & City & 298 \\
\hline Drink & 93 & Great & 282 & Polish & 63 & Visit & 305 & Clean & 70 \\
\hline Good & 169 & Market & 299 & Rebuilt & 117 & & & Come & 40 \\
\hline Hall & 142 & Night & 75 & Small & 73 & & & Day & 126 \\
\hline Hous & 106 & One & 147 & Still & 57 & & & Every & 78 \\
\hline Market & 327 & People & 131 & Town & 647 & & & Full & 93 \\
\hline Museum & 67 & Pretty & 44 & War & 129 & & & Get & 91 \\
\hline Must & 93 & Restaur & 433 & World & 72 & & & Historic & 155 \\
\hline Nice & 281 & & & & & & & History & 170 \\
\hline Night & 89 & & & & & & & Interest & 87 \\
\hline People & 130 & & & & & & & Just & 150 \\
\hline Polish & 66 & & & & & & & Lot & 326 \\
\hline Pretty & 43 & & & & & & & Love & 249 \\
\hline Pub & 63 & & & & & & & Main & 132 \\
\hline Restaur & 486 & & & & & & & Stay & 52 \\
\hline Sit & 54 & & & & & & & Much & 105 \\
\hline Squar & 741 & & & & & & & Plenty & 107 \\
\hline Surround & 56 & & & & & & & Recommend & 71 \\
\hline Watch & 89 & & & & & & & See & 222 \\
\hline & & & & & & & & Shop & 338 \\
\hline & & & & & & & & Stay & 56 \\
\hline & & & & & & & & Street & 212 \\
\hline & & & & & & & & Stroll & 51 \\
\hline & & & & & & & & Take & 117 \\
\hline & & & & & & & & Tour & 138 \\
\hline & & & & & & & & Visit & 257 \\
\hline & & & & & & & & Walk & 356 \\
\hline & & & & & & & & Will & 75 \\
\hline & & & & & & & & Would & 60 \\
\hline
\end{tabular}

Source: author.

much about the brand elements of the city (such words as 'also', 'feel' or 'find'). In order to not obscure the image of the cities examined during further analysis, it was decided to remove them. After this procedure, 42 words remained.

Afterwards, a correspondence analysis was made for such a data set (Hill, 1974). This is a descriptive and exploratory technique, providing information about the structure of connections between columns (variables) and rows (cases) on a hierarchical table (Stanisz, 2007, p. 307). It provides similar results to factor analysis but for qualitative data.

Before the correspondence analysis was started, a Pearson's $\chi^{2}$ test (for 95\% confidence level) for the data table was performed (42 cases - number of words x 5 variables - number of words on individual cities).
The result is shown below:

$$
\chi^{2}=4528.71, \mathrm{df}=164, \mathrm{p}<0.0001
$$

The test showed that there is a statistical relationship between the studied cases and variables at the significance level of $p<0.0001$. In the next step a correspondence analysis was carried out, as a result of which four dimensions were obtained, of which the first two were statistically significant. The first dimension explained as much as $78.3 \%$ of the variance of variables and together with the second dimension, explained almost $90 \%$ of the variances of the studied variables, which was considered a very good result (Table 4) (see Stanisz, 2007).

The obtained results were presented in the form of a two-dimensional graph (Fig. 2), where squares represent individual cities, and circles represent individual 
Table 4 . The results of correspondence analysis

\begin{tabular}{|c|c|c|c|c|c|}
\hline Dimension & Singular values & Eigen-values & \% of inertia & Cumulative \% & $\chi^{2}$ values \\
\hline 1 & 0.337 & 0.114 & 78.28 & 78.28 & $3545.063^{\mathrm{a}}$ \\
\hline 2 & 0.120 & 0.014 & 9.95 & 88.24 & $450.915^{\mathrm{a}}$ \\
\hline 3 & 0.101 & 0.010 & 6.96 & 95.20 & 315.429 \\
\hline 4 & 0.084 & 0.007 & 4.79 & 100.00 & 217.308 \\
\hline
\end{tabular}

Note: a - statistically significant values at $p<0.05$.

Source: author.

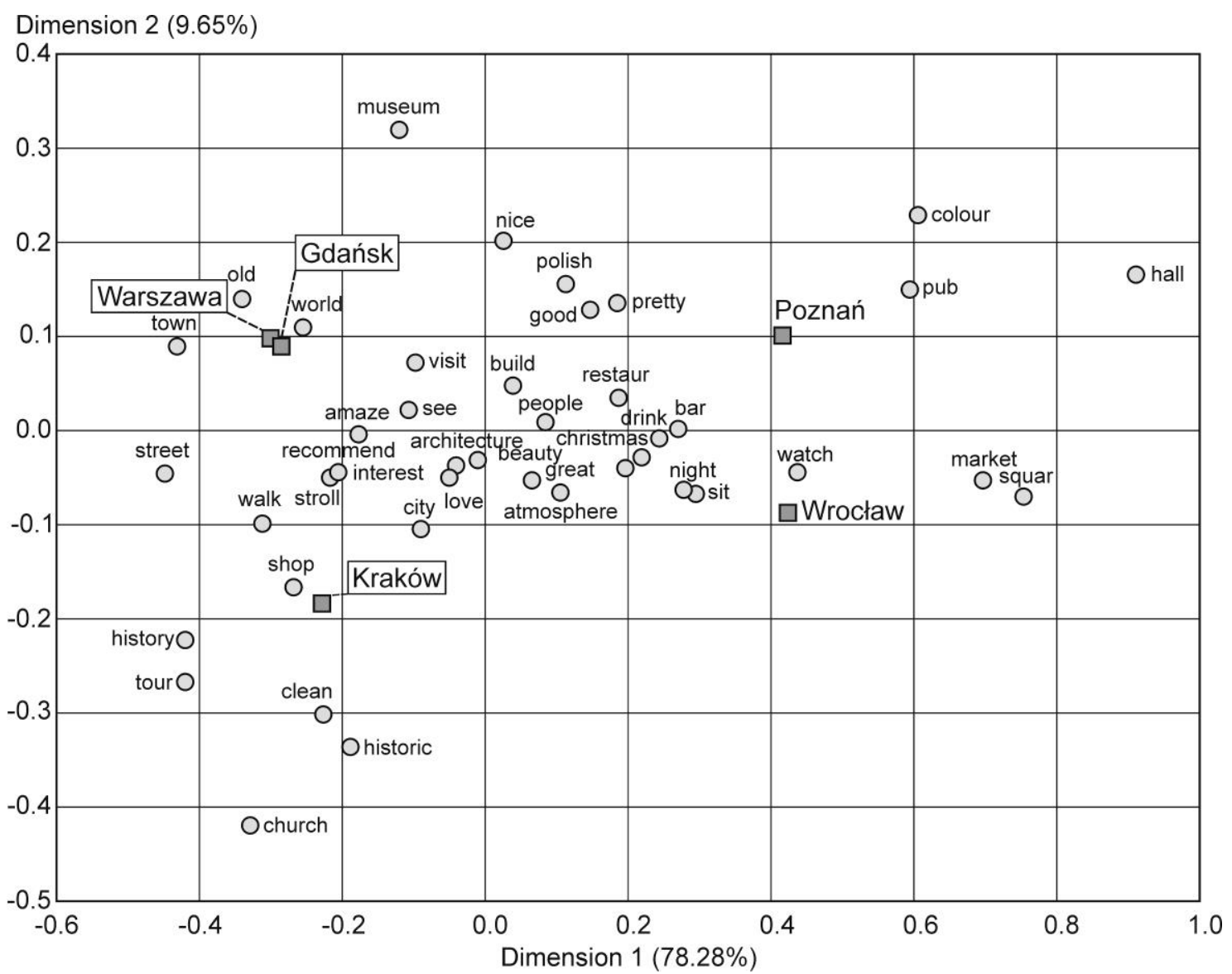

Fig. 2. Two-dimensional graph of row and column dimensions for 43 words and five cities Source: author

words. The graph shows that Kraków is located at a considerable distance from other cities. The words that most distinguish Kraków from the others are shop, walk, clean, history tour, and church. The next two cities, which are almost at the same point on the graph, are Warsaw and Gdańsk and are characterized by words such as old town, world or museum in the comments. The final two cities, also relatively close to each other, are Poznań and Wrocław and their words include drink bar, Christmas atmosphere, market square, market hall, restaurant, pretty, good, Polish, night, sit.

\section{DISCUSSION AND CONCLUSIONS}

The purpose of the above research was to identify the characteristic elements of the Polish city brands and to indicate the similarities and differences between them. This goal was accomplished by performing Text Mining, ANOVA and correspondence analysis, on a large quantity of data -5125 reviews available on TripAdvisor.

The performed research allowed to identify specific words - elements of the brand, which differ the examined cities (specifically the areas of old markets/ old 
towns). These elements can be used in creating marketing messages, website content, creating tourist products and even in attempts to build or modify existing territorial brands and images of tourist destinations.

The most specific words - brand elements - have been identified for Kraków and Poznań. In the light of the analyses, Kraków can be associated with historical tours, walks through the streets of a clean city, but also as a city with interesting shopping opportunities. Associations with Poznan are a colourful city full of pubs, a beautiful town hall, great bars, pubs and restaurants as well as an interesting nightlife. It was found that there are similar elements for Gdańsk and Warsaw, as well as for Poznań and Wrocław. The Kraków brand is characterized by the greatest uniqueness in relation to the others.

The above studies show that Poznań and Wrocław, as well as Warsaw and Gdańsk, may become the target of further comparative researches using CBBE, as they meet the conditions indicated by Leicht (2016) previously mentioned. In these studies, the unique elements of the city brands identified above could be used.

A limitation of the above research is the use of a single category (old market or old town) in the analysis. In further research it would be worth expanding the analysis to other attractions located in the city (in TripAdvisor's category 'Things to do...'), as well as restaurants and hotels, thanks to which the analysed elements of the city brand, and thus the city brand equity model, would become fuller. It is also worth identifying the forms of activities and tourists experiences which are characteristic of the studied cities, which together with the above-mentioned characteristic elements could be used in shaping tourism products, marketing strategies and in creating equity of city brands.

\section{ENDNOTES}

${ }^{1}$ Internet (Web 2.0) - definition of internet websites in which the content generated by the users of a given website plays a fundamental role.

2 For example, TripAdvisor - the world's largest travel site - contains 702 million reviews of 8 million hotel beds, airlines, tourist attractions and restaurants in 49 countries. Every month, 490 million unique users use the information contained therein (TripAdvisor. Media Centre).

3 The sum of words is greater than 74 because a few words were considered characteristic for several cities.

\section{BIBLIOGRAPHY}

Aaker, D.A. (2009). Managing brand Eequity: Capitalizing on the value of a brand name. New York: The Free Press.

Allahyari, M., Pouriyeh, S., Assefi, M., Safaei, S., Trippe, E.D., Gutirrez, J.B., Kochut, K. (2017). A brief survey of text mining:
Classification, clustering and extraction techniques, ArXiv e-prints, Halifax: KDD Bigdas.

Boo, S., Busser, J., Baloglu, S. (2009). A model of customer-based brand equity and its application to multiple destinations. Tourism Management, 30, 219-231.

Brown, G., Getz D., 2005. Linking wine preferences to the choice of wine tourism destinations. Journal of Travel Research, 43 (3), 266-276.

Buhalis, D. (2000). Marketing the competitive destination of the future. Tourism Management, 21 (1), 97-116.

Cantallops, A.S., Salvi, F. (2014). New consumer behavior: A review of research on eWOM and hotels. International Journal of Hospitality Management, 36, 41-51.

Casalo, L.V., Flavian, C., Guinaliu, M., Ekinci, Y. (2015). Do online hotel rating schemes influence booking behaviors? International Journal of Hospitality Management, 49, 28-36.

Florek, M. (2014). Kapitat marki miasta zorientowany na konsumenta. Źródła i pomiar. Poznań: Wydawnictwo Uniwersytetu Ekonomicznego w Poznaniu.

Hill, M.O. (1974). Correspondence analysis: A neglected multivariate method. Journal of the Royal Statistical Society. Series C (Applied Statistics), 23 (3), 340-354.

Jalilvand, M.R. (2016). Word-of-mouth vs. mass media: Their contributions to destination image formation. Anatolia, 28 (2), 151-162.

Jalilvand, M.R., Shekarchizadeh, S.S., Samiei, N. (2011). Electronic word-of-mouth: Challenges and opportunities. Procedia Computer Science, 3, 42-46.

Keller, K.L. (1993). Conceptualizing, measuring and managing customer-based brand equity. Journal of Marketing, 57 (1), 1-22.

Kenneth, S., Bordens, K.S., Abbott, B.B. (2008). Research design and methods. A process approach. Seventh Edition. New York: McGraw-Hill.

Kladou, S., Mavragani, E. (2015). Assessing destination image: An online marketing approach and the case of TripAdvisor Journal of Destination Marketing \& Management, 4 (3), 187-193.

Konecnik, M., Gartner, W. (2013). Customer-based brand equity for a destination. Annals of Tourism Research, 34 (2), 400-421.

Kotler, P.T., Bowen, J.T., Makens, J., Baloglu, S. (2017). Marketing for hospitality and tourism (7th edition, Global Edition). Essex: Pearson.

Kuhzady, S., Ghasemi, V. (2019). Factors influencing customers' satisfaction and dissatisfaction with hotels: A text-mining approach, Tourism Analysis, 24 (1), 69-79.

Leicht, T. (2016). Establishing external validity for consumerbased place brand equity scales: Mission impossible or a matter of approach? In: T.C. Melewar, K. Dinnie, C. Fona, C. Dennis (eds), Conference proceedings of inaugural conference of the international place branding association (pp. 248-256). London: Middlesex University.

Liu, Y., Huangb, K., Bao, J., Chenc, K. (2019). Listen to the voices from home: An analysis of Chinese tourists' sentiments regarding Australian destinations. Tourism Management, 71, 337-347.

Lucarelli, A. (2012). Unraveling the complexity of "city brand equity": A three-dimensional framework. Journal of Place Management and Development, 5 (3), 231-252.

Nakaima, K., Marchiori, E., Cantoni, L. (2019). Identification of competing destination brand: The case of Okinawa Island. In: J. Personen, J. Neidhardt (eds), Information and Communication Technologies in Tourism. Cham: Springer.

Niezgoda, A. (2017). Rola doświadczeń i relacji z podróży w kształtowaniu wizerunku miejsca. Marketing $i$ Zarządzanie, 1 (47), 221-228.

Nowacki, M. (2017). Atrakcje turystyczne światowych metropolii w opinii użytkowników TripAdvisora. Studia Periegetica, 3 (19), 23-41. 
Nowacki, M. (2019). World cities' image in TripAdvisor users' reviews. e-Review of Tourism Research (eRTR), 16 (2/3), 146-155.

Papadopoulos, N. (2004). Place branding: Evolution, meaning and implications. Place Branding, 1 (1), 36-49.

Pike, S. (2005). Tourism destination branding complexity. Journal of Product \& Brand Management, 14 (4), 258-259.

Pl.Wikipedia. Retrived from: https://pl.wikipedia.org/wiki/ Web_2.0.

Simeon, M.I., Buonincontri, P., Cinquegrani, F., Martone, A. (2017). Exploring tourists' cultural experiences in Naples through online reviews. Journal of Hospitality and Tourism Technology, 8 (2), 220-238.

Smith, M., Sulyok, J., Jancsik, A., Puczkó, L., Kiss, K., Sziva, I., Papp-Váry, Á.F., Michalkó, G. (2018). Nomen est omen - Tourist image of the Balkans. Hungarian Geographical Bulletin, 67 (2), 173-188.
Stanisz, A. (2007). Przystępny kurs statystyki z zastosowaniem STATISTICA PL na przykładach z medycyny. Vol. 3: Analizy wielowymiarowe. Kraków: StatSoft.

Tamajón, L.G., Valiente, G.C. (2015). Barcelona seen through the eyes of TripAdvisor: Actors, typologies and components of destination image in social media platforms. Current Issues in Tourism, 20 (1), 33-37.

TripAdvisor. Retrieved from: https://www.tripadvisor.co.uk (15.01.2019).

TripAdvisor. Madia Centre. Retived from: https://tripadvisor. mediaroom.com/uk-about-us (18.02.2019).

Web Scraper. Retived from: https://www.webscraper.io/ (17.01.2019).

Woodside, A.G., Cruickshank, B.F., Dehuang, N. (2007). Stories visitors tell about Italian cities as destination icons. Tourism Management, 28, 162-174.

Article received:

12 March 2019

Accepted:

6 May 2019 